\title{
Rodent damage to rice crops is not affected by the water saving technique Alternate Wetting and Drying
}

\author{
Renee P. Lorica ${ }^{1,2}$, Grant R. Singleton ${ }^{1,2}$, Alexander M. Stuart ${ }^{1}$, Steven R. Belmain ${ }^{2}$ \\ ${ }^{1}$ Sustainable Impact Platform, International Rice Research Institute, Los Baños, Laguna 4031 Philippines \\ ${ }^{2}$ Natural Resources Institute, University of Greenwich, Chatham, Kent ME4 4TB UK
}

Correspondence: reneelorica@gmail.com

RPL ORCID: https://orcid.org/0000-0002-5957-3722

GRS ORCID: https://orcid.org/0000-0002-2154-1223

AMS ORCID: https://orcid.org/0000-0002-7804-2628

SRB ORCID: https://orcid.org/0000-0002-5590-7545

\begin{abstract}
Rice farmers in Southeast Asia are hesitant to adopt the water-saving technology, Alternate Wetting and Drying (AWD), for fear the practice will lead to increased rodent pest activity, consequently exacerbating yield loss. We examined the effects of AWD on the population dynamics, habitat use and damage levels inflicted on rice crops by the most important rodent pest of rice in Indonesia and the Philippines, Rattus argentiventer, and R. tanezumi, respectively. Rice crop damage levels were not affected by the water management scheme employed. Rodent activity in rice fields was not influenced by water level. Both species tended to use the rice paddies over bunds regardless of water level, indicating that something other than water affects their habitat use, and we argue it is likely that the perceived risk of predation is the primary factor driving habitat use. Activity levels and damage inflicted by rodent pests on rice are, therefore, not correlated. AWD had no effect on breeding and population dynamics of these species. Breeding of $R$. argentiventer is tied to the growth stages of rice whilst available resource dictates breeding by $R$. tanezumi. Our findings clearly indicate that rice farmers in both Indonesia and the Philippines have no cause to reject AWD based on concerns that AWD would exacerbate crop losses by rodents. Given AWD is being promoted as a climate-smart technology for rice production in Asia and Africa, we strongly recommend its adoption without concerns that it would aggravate rodent pest impacts in lowland irrigated rice cropping systems.
\end{abstract}

KEY WORDS: Rodent pests, Damage, Population dynamics, Habitat Use, Rattus argentiventer, Rattus tanezumi 


\section{KEY MESSAGE}

- The effect of AWD on damage levels inflicted on growing rice crops by Rattus argentiventer and R. tanezumi, their population dynamics, and habitat use were investigated.

- AWD has no effect on rice damage levels, rodent pest population dynamics and habitat use.

- Breeding of $R$. argentiventer is tied to the growth stage of rice whilst for $R$. tanezumi, it is cued by availability of food resources.

- Habitat use is likely driven by perceived predation risk.

- Adopting AWD will not lead to higher rodent pest activity.

\section{AUTHOR CONTRIBUTION STATEMENT}

GRS conceived the topic. RPL, GRS and SRB conceived the research. RPL conducted the field work and analyzed the data. AMS assisted with data analysis. All the authors contributed to the writing of the manuscript.

\section{INTRODUCTION}

More than $90 \%$ of global rice production is produced and consumed in Asia (GRiSP (Global Rice Science Partnership) 2013). Rice is the largest consumer of water in agriculture (Dawe 2005; GRiSP 2013). With the increasing demand for rice coupled with the decreasing supply of freshwater amidst the changing climate (Bouman et al. 2007), there is an urgent need to produce more food with less inputs and to save on water. Alternate Wetting and Drying (AWD), also known as controlled or intermittent irrigation, is a technique developed to increase water productivity (amount of food produced per unit of total water input) in lowland irrigated rice, and to save on water for other purposes, or for further distribution along the irrigation system (Bouman et al. 2007; Bouman and Tuong 2001). Safe AWD entails allowing water in rice fields to dry to $15 \mathrm{~cm}$ below the surface, except during flowering, before flooding it again (Bouman and Tuong 2001). This practice is implemented by monitoring water levels by using a field water tube made from a $30 \mathrm{~cm}$-long plastic or bamboo pipe. Half the tube is perforated with holes so the measurement of water in the tube will be more reliable. The tube is then buried halfway in an area of the paddy that is easily accessible but is representative of the field level (Bouman et al. 2007).

The positive effects of AWD on water savings and productivity of rice are: maintaining yields whilst reducing water use by more than 20\% (Lampayan et al. 2015; Pan et al. 2017); reduction of methane gas emissions by more than 35\% (Johnson-Beebout et al. 2009; Sander et al. 2015; Siopongco et al. 2013); reduced lodging of rice due to better root establishment (Pan et al. 2017); and savings on fuel cost when water is pumped for irrigation (Rejesus et al. 2011; Valdivia et al. 2016). The relationships among water users in an area that provide effective implementation of AWD have been evaluated in several countries, and for different soil types and under a variety of crop management conditions (Bouman et al. 2007; Bouman and Tuong 2001; Lampayan et al. 2015). Despite this, some rice farmers are hesitant to adopt AWD for fear the practice will lead to increases in rodent pest activity, consequently exacerbating 
yield loss (R. Flor, R. Lampayan, pers. comm.). Farmers in the Philippines and Vietnam reported problems on rats when they used AWD (Quynh and Sander 2015; Richards and Sander 2014). A farmer survey in Bohol, central Philippines, revealed that farmers practicing AWD ranked rats as the primary pest of rice (Smedley 2017). Rodents also are among the top three pests of rice in the Philippines (Singleton 2003).

Rodents are arguably most notorious for the threat they pose to food security (John 2014; Meerburg et al. 2009). Pre-harvest losses in 11 countries in Asia range from 5-17\% annually, with Indonesia sustaining the highest damage nationally, although some districts in Bangladesh reported $>50 \%$ loss (Singleton 2003). In Africa, total crop losses for maize, rice and wheat were reported to be around $15 \%$, though seedling losses were much higher, at ca. 50\% (Swanepoel et al. 2017). To put this in perspective, a 5\% loss could feed 181 million people per year (Singleton et al. 2003). It is, therefore, understandable that farmers will be hesitant to adopt a measure when they think this will lead to more rodent damage to their rice. However, it is unknown how rodent pests actually respond to periodic drying of the growing rice crop. This study was designed to address this knowledge gap. The most abundant and problematic rodent pest species of rice was investigated in each country: the rice field rat (Rattus argentiventer Robinson \& Kloss, 1916) in Indonesia, and the Oriental house rat (Rattus tanezumi Temminck 1844) in the Philippines. R. argentiventer is well adapted to rice growing in flooded environments (Leung et al. 1999) so we expect that the level of damage that they do to rice crops would not be affected by regular draining of water from a rice crop. We therefore hypothesize for both species of rodents that their habitat use and the level of damage they cause to irrigated rice will not be affected by AWD practices.

\section{MATERIALS AND METHODS}

Study area

The first study area was located in the island of Java, within the Special Region of Yogyakarta in Minggir, Sleman Regency ( $7^{\circ} 43^{\prime} \mathrm{S}, 110^{\circ} 15^{\prime} \mathrm{E}$ ) (Fig. 1). Farmers were randomly selected from a group who were once part of a study on ecologically-based rodent management (EBRM) from 2012-2014. Yogyakarta experiences type Am (tropical monsoon) climate (Peel et al. 2007).

Fig. 1. Location of the study area, Minggir in the Special Region of Yogyakarta in the Indonesian island of Java.

In the Philippines, the study area was located in Bula, Camarines Sur, Bicol Region in Southern Luzon (13 ${ }^{\circ}$ $\left.30^{\prime} \mathrm{N}, 123^{\circ} 18^{\prime} \mathrm{E}\right)$ (Fig. 2). This area was within a larger IRRI project evaluating the adoption and impact of AWD on irrigated rice that stratified all the fields within the project into either AWD or control. Farmers were randomly selected from each of these stratifications. This IRRI project encompasses the entire Rinconada Integrated Irrigation System (RIIS) in Camarines Sur, Bicol Region. The RIIS services 7,031 hectares of rice fields as of 2013. In addition, Bicol Region has one of the highest rodent damage rates on rice in the Philippines (Singleton, pers. comm.). The KöppenGeiger classifies Bula as Af (tropical rainforest) climate (Peel et al. 2007). 
Fig. 2. Location of the study site in Bula, Camarines Sur, Philippines.

For both countries, once farmers were randomly selected, ground-truthing for field area measurement and to ensure the similarity in habitat type surrounding the rice environment was conducted. Fields were similar in age of crop, size, and sufficiently proximate such that all fields could be visited within two hours, but far apart enough from each other that rodent populations in each replicate do not overlap. These criteria are crucial because all traps need to be checked with all rats processed and released before midday. Based on previous research on the home ranges of rodent species, each replicate had a minimum buffer radius of $170 \mathrm{~m}$ for $R$. tanezumi (Miller 2007) and $100 \mathrm{~m}$ for $R$. argentiventer (Jacob et al. 2003a) from each other to ensure the independence of rodent populations per replicate. The minimum buffer radius for each country was computed from the square root of the home range of the respective species.

Study design

Each site (country) had three replicates of AWD and non-AWD (control) fields. In control fields, water was managed conventionally by farmers, whilst AWD fields were irrigated intermittently. In Indonesia where the farm holdings are small (ca. 1,000 $\mathrm{m}^{2}$ ), adjacent fields were aggregated to form a plot measuring about a hectare. The adjacent plot, measuring about the same size, was designated as treatment (AWD). These treatment-control pairs were designed as matched pairs to examine the preference of local rodent populations for the two water management schemes (Fig. 3).

Fig. 3. Locations of the three paired replicates in Minggir, Yogyakarta, Indonesia in 2016. Fields bound by white are control whilst those bound by blue are AWD.

In the Philippines, rodent trapping was located within a turnout service area (TSA) that was stratified according to the water management scheme (either as AWD or control) then randomly selected within a stratum. A turnout service area is where the water is distributed to various farms from the main irrigation canal. A TSA in RIIS typically caters for 10 to 50 hectares of rice fields. Three AWD TSAs and three control TSAs were randomly selected for the study (Fig. 4).

Fig. 4. Location of the trapping areas within the TSAs in Bula, Camarines Sur, Philippines for the two seasons of data gathering. Red dots are AWD replicates whilst blue dots are control replicates. 
Based on previous research on the home ranges of these species, each replicate had a minimum buffer radius of $170 \mathrm{~m}$ for $R$. tanezumi (Miller, 2007) and $100 \mathrm{~m}$ for R. argentiventer (Jacob et al. 2003a) from each other to facilitate independence of rodent populations per replicate. The minimum buffer radius for each country was computed from the square root of the home range of the respective species. Trapping of rodents was conducted during the following stages of the dry season rice crop [per location per site per year]: maximum tillering, panicle initiation/booting, flowering, and milky (ripening). Trapping regimes were slightly different for each country due to the size of the study sites and because $R$. argentiventer rarely enters live-capture traps set without a drift fence due to very trap-shyness (GR Singleton and Sudarmaji pers. com.).

In Indonesia, one Linear Trap Barrier System (LTBS) with six multiple-capture traps (MCT) was established in each of the AWD and control fields. Each trap was spaced $20 \mathrm{~m}$ from the next, alternating on either side of the LTBS. Six single-capture traps (SCT) spaced $10 \mathrm{~m}$ from each other were also placed in each field. Approximately 200 $\mathrm{m}$ away from the trapping grid, 12 kill-traps (Kness Big Snap-E® traps) were deployed in same-age rice fields to assess the breeding status of rodents in the area. Snap traps, spaced $10 \mathrm{~m}$ apart, were tied to bamboo sticks with a white marking at the end for better visibility in the surrounding vegetation. In the Philippines, each field had 15 MCTs and 15 SCTs, but no kill-traps were deployed due to high likelihood of them being pilfered. The MCTs were spaced $20 \mathrm{~m}$ apart while the SCTs were spaced $15 \mathrm{~m}$ apart. Traps set to capture $R$. argentiventer were baited with a combination of rice, coconut and corn (Leung et al. 2007). In the Philippines, traps set to capture $R$. tanezumi were baited with fresh coconut and golden apple snail (Stuart et al. 2014). Live-traps were covered with vegetation to provide shelter from rain or sun. In both countries, trapping was done for three consecutive nights per location per crop stage. At completion of a trapping session, the traps were removed. Traps were set in the afternoon and checked early morning the following day for three consecutive nights. Captured rats were ear marked with uniquely numbered ear tags, measured (head-body length, foot length, ear length), sexed and weighed. Reproductive data were collected, whereupon the animal was released.

Spool-and-line tracking has been used since the 1920s to study animal movement (Aplin et al. 2003). It involves attaching a bobbin-less cocoon of thread to an animal then releasing the animal and following the spool trail. Individual paths were considered as the unit of replication as done in previous spool-and-line tracking studies (Cunha and Vieira 2002; Loretto and Vieira 2005; Prevedello et al. 2009). Bobbin-less cocoons of nylon thread number 72/10 (Imperial Threads, Inc., Northbrook, Illinois) were used. Spools were fitted with heat-shrink tubing to prevent the thread from unravelling prematurely and catching on vegetation (Boonstra and Craine 1986). Each spool had an approximate length of $300 \mathrm{~m}$, weighing $4.5 \mathrm{~g}$ with the heat-shrink tube. Only animals over $80 \mathrm{~g}$ were fitted with a spool so that the weight of the spool (less than $5 \%$ of body weight) would not interfere with the movement of the animals (Sikes and Gannon 2011). The spool was attached to the fur between the shoulders using cyanoacrylate glue (Boonstra and Craine 1986). The loose end of the thread was knotted around vegetation together with flagging tape labelled with the identification of the animal. Each animal was placed in a single capture trap to permit recovery for a few minutes prior to release. All spooled rats were released at the point of capture in the same morning. Different colored nylon threads were attached to the rats per replicate per day to distinguish between individual trails. The trail left by the spool line was followed in the afternoon of the same day to locate the daytime refugia. The same spool trail 
was followed the next morning to document the habitat traversed by the rat during its regular hours of activity. The first five meters was excluded to account for the flight response of the animal, and only paths longer than $15 \mathrm{~m}$ were included in the analysis (My Phung et al. 2012; Stuart et al. 2007). A modification of Stuart et al. (2007) was used to assess habitat use. Save for the first $10 \mathrm{~m}$, microhabitat data was recorded every ten meters along the spool line. Microhabitat characteristics (type of cover, water depth) was assessed within a one-meter radius around each ten meter-mark. Spool trails and any refuge used by the animal were recorded using a Global Positioning System (GPS) receiver.

Minimum Number Known Alive (MNKA) was used to provide an estimate of rodent abundance (Krebs 1966). Populations were assumed to be closed since trapping periods were short ( 3 consecutive nights) (Jacob and Matulessy 2004). Females caught in the kill-traps were dissected and assessed for the following reproductive criteria: lactation (not visible, visible with hair, visible without hair), vaginal condition (perforate or imperforate), uterine scars (present/absent; if present, number), gestation (yes/no; if yes, number of embryos and embryonic stage). Male reproduction was assessed based on external observation of the testes: undescended, partially descended and fully descended. This follows the protocol from Aplin et al. (2003). Females were considered to be in breeding condition if they were determined to be lactating or pregnant by palpation (only from the second trimester onwards) (Aplin et al. 2003).

Damage assessments for transplanted rice in Indonesia involved counting the number of damaged (fresh cut + regrowing) and undamaged (uncut) tillers per hill (Aplin et al. 2003), and followed Stuart et al. (2014) with regards to the lay-out of transects. In the study site in the Philippines, rice was direct-seeded so a sampling point was defined as all the tillers inside a $0.1 \mathrm{~m}^{2}$ quadrat (Stuart et al. 2014). This small quadrat, according to Stuart et al. (2014), has approximately the same number of tillers as in a transplanted sampling point. The lay-out of transects followed that of the transplanted rice. There were three transects in each field. This lay-out ensures that rodent activity is represented in the gradient as one goes further away from a refuge habitat (e.g. an irrigation canal) or a completely different habitat (e.g. a road). Tillers of rice are typically cut by rodents at a $45^{\circ}$ angle (Aplin et al. 2003), which at the vegetative to the reproductive stages will be closer to the base of the rice. However, at ripening stage, cuts usually occur higher up the tiller close to the base of the panicles.

\section{Analysis}

Spool-and-line data were derived from tracks recorded by the GPS. Data were imported into QGIS ${ }^{\circ}$ 3.0.2 to measure the portion of each spool that was inside each plot, outside of the study plots, and those that ventured into either the treatment or control plots. SPSS 24 (IBM Corp. 2016) was used to generate the graphs and statistically analyze all the data, unless otherwise specified. Spearman's Rank-order Correlation was used to quantify the relationship between the number of rats and water levels. Tortuosity, or the convolutedness of a path, was measured using Straightness Index (SI) (Batschelet 1981). SI is the ratio of the straight-line distance to the total distance between the start and end points of a traverse (Benhamou 2004; Miller et al. 2011), and values range from 0 to 1, where a path is more tortuous as it approaches 0 . SI is a measure of efficiency of the animal's orientation whilst moving towards a 
goal (Batschelet 1981). The association between SI and length of spool, and SI and water was quantified using Spearman's Rank-order Correlation. This test of association was used due to the non-conformance of the data to the assumptions of its parametric equivalent.

Spooling data was log-transformed due to non-normality of its distribution. Linear mixed-effect models and ANOVA (Analysis of Variance) in R 3.5.1 (R Core Team 2018) was used to analyze data on the distribution of spools in Indonesia inside each plot where the rats were released; outside of the study plots; and those that ventured into the adjacent treatment or control plots. For group means with statistically significant difference, Tukey's honestly significant difference (HSD) was used post hoc to confirm where the difference occurred between groups. This type of analysis could not be done for the Philippines because the setup of the experiment was such that the treatment and control fields were not adjacent to each other, unlike in Indonesia.

Paired samples t-test was used to compare between captures of rodents, water levels, and damage levels from AWD and control fields in Indonesia given AWD fields were located adjacent to control fields. In the Philippines where AWD fields were separate from control fields, an independent samples t-test was used for each variable. A linear mixed model with maximum likelihood estimation was used to analyze the effect of AWD on damage levels. Repeated measures included in the model are season (year) and crop stage. Fixed effects entered in to the model and their interactions include crop stage, treatment, number of rats, and water levels.

\section{RESULTS}

Indonesia

Mean water level measurements from the water tubes in 2016 show that those in the AWD fields $(-8.16 \mathrm{~cm}$ $\pm 0.64)$ was significantly lower $\left(t_{130}=2.553, p=0.012\right)$ that those in the control fields $(-5.76 \mathrm{~cm} \pm 0.69)$. In 2016 , damage was highest in the ripening stage for both the control and AWD fields. Mean damage was significantly higher $\left(t_{11}=3.299, p=0.007\right)$ in the control fields $(2.44 \pm 6.19)$ than in the AWD fields $(10.55 \pm 3.0)$. In 2017, there was no difference in damage levels $\left(t_{8}=1.895, p=0.095\right)$ between AWD fields $(8.75 \pm 2.9)$ and the control fields $(9.03 \pm$ 3.01). Damage peaked during the flowering stage in both the control and AWD fields in 2017. The linear mixed model with maximum likelihood estimation showed significance with the main effect of water $\left(F_{1,20.13}=5.068, p=0.036\right)$ and interactions of crop stage by number of rats $\left(F_{2,24.36}=3.328, p=0.053\right)$, treatment by water $\left(F_{1,20.12}=5.119, p=\right.$ $0.035)$, and crop stage by treatment by number of rats, $\left(F_{1,32.60}=5.679, p=0.023\right)$.

In 2016, AWD fields had significantly higher number of rats captured $(n=50,4.17 \pm 0.920)$ compared to the control fields ( $\mathrm{n}=10,0.83 \pm 0.386)\left(t_{11}=-3.640, p=0.004\right)$. There was no association between water level and number of rats $\left(r_{s}(24)=0.147, p=0.493\right)$. Mean litter size was $8.7 \pm 1.64$ in AWD fields and $9.14 \pm 1.42$ in control fields. In 2017, water readings from the AWD tubes $(-5.03 \mathrm{~cm} \pm 0.79)$ were significantly lower $\left(t_{157}=3.607, p<0.001\right)$ than those from the control fields $(-1.09 \mathrm{~cm} \pm 0.65)$. AWD fields had similar numbers of rats captured $(\mathrm{n}=24,2.67 \pm 1)$ as the control fields ( $\mathrm{n}=27,3 \pm 0.886),\left(t_{8}=0.359, p=0.729\right)$ (Fig. 5). The mean litter size for 2017 was $10.83 \pm$ 2.68. There was no relationship between water and number of rats $\left(r_{s}(18)=0.375, p=0.125\right)$. 
Fig. 5. Mean $( \pm S E)$ number of rats trapped against the mean $( \pm S E)$ water levels in AWD rice and conventionally irrigated rice (control) crops in Indonesia throughout the different growth stages of rice in (a) the 2016 cropping season and (b) the 2017 cropping season. Line graph represents mean water levels; bar graph represents mean number of rats.

For rats released in the control fields $(n=20)$, the percentage of spools per crop stage that stayed within the control fields were as follows: Max tillering 62.7\%; Booting 44.5\%; Flowering 70\%; and, Ripening 76\% (Fig. 6a). Rats rarely ventured into the adjacent AWD plot (Max tillering 8.7\%; Booting 0\%; Flowering 2.6\%; and, Ripening $0.06 \%$ ), but spent some time outside the study plot: Max tillering 28.6\%; Booting 55\%; Flowering 27.4\%; and, Ripening $24 \%$. Rats released in the AWD fields $(\mathrm{n}=22)$ tended to stay within the field most of time (Max tillering 72.9\%; Booting 54\%; Flowering 96\%; and, Ripening 62.4\%), and rarely ventured into the adjacent control plot (Max tillering 0.1\%; Booting 0\%; Flowering 1.4\%; and, Ripening 0.5\%) (Fig. 6). Rats also ventured outside of the study plots (Max tillering 26.9\%; Booting 5\%; Flowering 2.5\%; and, Ripening 37\%). Fig. 7 shows an example of spool trails by $R$. argentiventer in Indonesia.

Fig. 6. Percentage of spool lengths of all rats in (a) the control and(b) the AWD plots in 2016 and 2017 throughout the different crop stages. IN is the percentage of the total length of spools which were scored within the respective plots where rats were caught; OUT is the percentage of the total length of spools that were scored outside of the study area. AWD is the percentage of the total length of control spools that were scored in the AWD plots, and CONTROL is the percentage of the total length of AWD spools that were scored in the control plots.

Fig. 7. Spool trails of rats from Replicate 2 in 2017 in Indonesia. Different colors correspond to different individuals. The AWD field is bound by blue dotted line whilst the control field is bounded by white dotted line.

There was a significant interaction between crop stage and track location $\left(F_{6,58}=0.16, p=0.032\right)$ in the twoway ANOVA (

Table 1). Tukey's HSD post hoc test indicates that the comparisons between spools that went outside of the study area during flowering and booting $(p<0.05)$, and spools that went outside of the study area during flowering and ripening $(p<0.05)$ were significant. There was a strong, negative correlation between the Straightness Index and length of segment of a spool $\left(r_{s}(174)=-0.318, p=0.000\right)$. Straightness Index had no correlation with water level $\left(r_{s}(174)=-0.024, p=0.749\right)$.

Table 1. ANOVA of the distribution of spools in Indonesia according to crop stage, track location (where the rats went after being released) and the interaction of crop stage and track location. 


\begin{tabular}{lccccc}
\hline & df & Sum Sq & Mean Sq & F-ratio & $p$ \\
\hline Crop stage & 3 & 15.98 & 1.36 & 1.25 & 0.2643 \\
Track location & 2 & 16.53 & 21.11 & 0.33 & 0.1306 \\
Crop stage*Track location & 6 & 59.03 & 1.51 & 0.16 & 0.0315 \\
Residual & & 58 & & & \\
\hline
\end{tabular}

Philippines

Rodent damage was significantly higher $\left(t_{28}=2.478, p=0.019\right)$ in $2016(4.03 \pm 1.65)$ than in $2017(0.55 \pm$ 0.35). In 2016, the level of damage in the control plots $(5.24 \pm 2.91)$ was similar $\left(t_{10}=-0.718, p=0.489\right)$ to the AWD plots (2.82 \pm 1.72$)$. In 2017, the level of damage in the AWD fields $(0.66 \pm 0.59)$ was similar to the control field $(0.45$ $\pm 0.39)\left(t_{16}=0.299, p=0.769\right)$. In 2016, for both the control and AWD fields, the mean damage peaked at the booting stage. In 2017, mean damage levels peaked during the flowering stage for the AWD plots, whilst it peaked during the ripening stage for the control plots. Mean damage was similar $\left(t_{16}=0.299, p=0.769\right)$ between AWD $(0.66 \pm 0.59)$ and the control plots $(0.44 \pm 0.39)$. The linear mixed model with maximum likelihood estimation with repeated measures for data from 2016 and 2017 showed that only crop stage $\left(F_{2,41.59}=41.599, p=0.000\right)$ and the interaction between crop stage by year were significant $\left(F_{1,7}=6.753, p=0.035\right)$.

In 2016, control fields had similar mean number of rats caught $(n=92,13.83 \pm 3.64)$ to the AWD fields ( $\mathrm{n}$ $=86,14.83 \pm 2.55)\left(t_{10}=0.225, p=0.826\right)$. Water had no relationship with rodent numbers $\left(r_{s}(12)=0.309, p=0.328\right)$ (Figure 5a). There was no difference between the proportion of breeding females in the AWD and control fields $\left(t_{4}=\right.$ $-1.069, p=0.36)$. In 2017, there was no difference in the mean number of rats caught from the AWD fields ( $\mathrm{n}=112$, $13.89 \pm 2.34)$ and the control fields $(\mathrm{n}=50,9.22 \pm 1.91)\left(t_{16}=1.543, p=0.142\right)$ (Figure 5b). There was a strong, negative correlation between the Straightness Index and length of segment of a spool $\left(r_{s}(134)=-0.526, p=0.000\right)$. The Straightness Index has no correlation with water $\left(r_{s}(134)=0.083, p=0.340\right)$. For both 2016 and 2017, only 14\% ( $\mathrm{n}=48$ ) of $R$. tanezumi were recaptured, $90 \%$ of which were by multiple-capture traps.

Fig. 8. Mean $( \pm S E)$ number of rats caught against the mean $( \pm S E)$ water levels in AWD rice and conventionally irrigated rice (control) crops in the Philippines throughout the different growth stages of rice in (a) the 2016 cropping season and (b) the 2017 cropping season. Line graph represents mean water levels; bar graph represents mean number of rats.

\section{DISCUSSION}


Our results indicate that AWD does not influence how much rodent damage is caused by $R$. tanezumi in the Philippines given similar damage levels in the control and AWD fields. Mean rodent damage to rice was influenced by neither water nor number of rats captured for both years of data gathering. Crop stage was an important factor influencing damage levels. In 2016, the highest damage was recorded during booting for both the control and the AWD fields. Similar findings was observed by Miller et al. (2008) for R. tanezumi in the rice terraces of Banaue, in northern Luzon, Philippines, and by Jones et al. (2017) for R. tanezumi in Laguna, Philippines. The interaction between crop stage and year reflects the significant difference between damage levels between crop stages in 2016 and 2017.

Results of the linear mixed effect model for $R$. argentiventer show that the main effect of water, and its interaction with treatment were significant perhaps because it affects the two types of water management quite differently in 2016 and 2017. Mean damage was significantly higher in the control fields although mean number of rats was significantly higher in AWD fields in 2016. In 2017, there was no difference in mean number of rats and damage between treatment and control. However, the interaction of crop stage, treatment and number of rats was also significant. Given that control fields have higher levels of damage than AWD fields, even if AWD fields had more rats in total, then it is also not intermittent irrigation that affects how much rats damage the fields in Indonesia.

AWD does not affect the timing of $R$. argentiventer and $R$. tanezumi damage in rice. Both AWD and control fields had the highest damage levels during the ripening stage in 2016 in Indonesia, and in 2017, damage peaked during flowering for both water management schemes. In the Philippines, damage was highest during booting stage for both control and AWD fields. This follows the pattern seen for the same species in the Philippines (Miller et al. 2008; Stuart et al. 2007). However, in 2017, damage was highest during flowering in the AWD fields and ripening in the control fields.

AWD does not have an effect on the number of captures of $R$. tanezumi in the Philippines because there was no difference between the mean number of captures from the AWD and control fields. A conclusion cannot be drawn from the mean number of captures of R. argentiventer in Indonesia since the setup of the fields is such that AWD and control plots in a replicate may share the same population. Trap catch of rats may have been influenced by trappability, prevailing environmental conditions, and human activities in the area, or a combination of these factors (Brown et al. 2005), rather than intermittent irrigation.

AWD had no effect on the breeding ecology of R. tanezumi as there was no significant difference between the proportion of breeding females caught between AWD and control plots. The proportion of breeding females of $R$. tanezumi in Bicol, Philippines peaked during maximum tillering and ripening stages for 2016 and 2017, concurring with the findings of Marges (1972). In north eastern Luzon, mean litter size is 4.2 (Stuart et al. 2012), which was similar with our findings for 2016. In Indonesia, there were not enough breeding $R$. argentiventer females caught to quantify the effect of AWD on the species' reproductive activity. Previous studies on the breeding ecology of $R$. argentiventer indicated that breeding was largely influenced by the growth stage of rice-from maximum tillering through to harvest (Brown et al. 1999; Jacob et al. 2003b; Leung et al. 1999; Tristiani et al. 1998). In Malaysia, breeding of $R$. argentiventer was confined to the reproductive stage of rice, both for the wet and dry seasons (Lam 1983). 
There was no association between the mean number of $R$. tanezumi and $R$. argentiventer caught with mean water levels, indicating no preference or avoidance of dry fields. There was also no association between the Straightness Index (SI) for this species and water levels, which means the animals will use a rice field regardless of water level. Previous studies show that rats thrive in both dry and wet conditions. In areas with prolonged flood, Fall (1977) observed rats were breeding in nests built in floating vegetation. The $R$. tanezumi in Miller (2007) was seen swimming in an open paddy with newly-transplanted rice in broad daylight. Stuart et al. (2012) found that in mixed rice-coconut areas, $R$. tanezumi preferred to nest above-ground to protect them from flooding and human activity. Previous studies, whilst not directly investigating the effect of water on $R$. argentiventer behavior, demonstrate that the species also do not prefer dry over wet environments, or vice-versa. Brown et al. (2001) and Brown et al. (2005) radio telemetry studies could not acquire more accurate fixes because $R$. argentiventer were detected swimming in the paddies. On the other hand, My Phung et al. (2012) found that spooled $R$. argentiventer tended to stay in the fields more during ripening and harvest, when the fields are dry. Rattus argentiventer created burrows in drained rice fields after harvest in Indonesia (Leung et al. 1999). In Tra Vinh, in the Mekong Delta, flooding caused rat population abundance to decline (Brown et al. 1999). Boonsong et al. (1999) and Pujiastuti et al. (2018) caught the most $R$. argentiventer in Thailand and Indonesia, respectively, during ripening when the fields were dry. The significance behind the difference in the amount of spool that left the study area in the post hoc comparison of SI between crop stages in Indonesia is unclear, and may reflect more of where the rats were released rather than any biological significance. The strong negative correlation between Straightness Index and length of segment of a spool indicates that the longer the path, the more likely it is to be convoluted (i.e. SI approaches zero). Animal movement towards a destination tends to be straighter than foraging behavior (Miller et al. 2011).

Spooled rats in this study also used the paddy more than the bunds, regardless of water level. Perhaps this is associated with how the rodents perceive the safety of their landscape (Krijger et al. 2017); the likelihood of predators chancing upon a moving animal is likely to be higher on the bunds than in the field. Bush rats in Victoria, Australia used microhabitat features such as logs and ground cover to move safely within the habitat, but will use them more in areas where predators have been removed (Strauss et al. 2008). Rattus lutreolus also preferred dense vegetation as protection from predators when foraging (Kearney et al. 2007). There was no food taken from giving up density (GUD) trays placed on bunds whilst trays in the middle of the field consistently had food taken by on R. tanezumi in lowland rice fields in the Philippines (Jones et al. 2017). Giving up density (GUD) is the density of resources remaining in a patch when an individual cease foraging (Brown 1988), which provides unbiased and controlled measure of the foraging cost of predation (Abu Baker and Brown 2010).

Water may not be the factor influencing the habitat use of both species of rats, given clear preference of both $R$. argentiventer and $R$. tanezumi to the paddy prior to harvest and the non-association of Straightness Index with water. How animals perceive risk of predation in different habitats, referred to as the landscape of fear (LOF) (Laundré et al. 2001), may have an influence on habitat use, not water. An animal may shift to areas with denser cover if a higher risk of predation is perceived (Brown 1988). Jones et al. (2017) reported that rats perceive the center of the rice field to have the lowest risk of predation due to cover. Common voles (Microtus arvalis Pallas, 1778) perceived unmowed grass at night to be safest compared with mowed grass, which was perceived as the riskiest (Jacob and 
Brown 2000). Similarly, the multimammate rat (Mastomys natalensis Smith 1834) in maize fields in Tanzania preferred giving up density (GUD) boxes with cover than those without cover in fields where birds of prey are allowed as opposed to areas with netting (Mohr et al. 2003). The spatial use in the current study based on the spool trails reflect the key findings of these previous studies on rodents in agricultural landscapes.

The significant interaction term in the two-way ANOVA performed on the mixed effects model on the distribution of spools of $R$. argentiventer in Indonesia means the segment lengths were different at different crop stages. Tukey's HSD post hoc test indicated further that it was the comparisons between Flowering.Out-Booting.Out, and Ripening.Out-Flowering.Out that were significant. This means that the segment of spools that went outside of the study plot was significantly higher between ripening and flowering than between flowering and booting.

The present study provides the first insight into the influence of the water-saving technology AWD to the habitat use of the pests $R$. argentiventer and $R$. tanezumi. The landscape of fear, not water, may be what drives the way these two species use their habitat prior to harvest of rice. Given that the landscape of fear seems to be what influences habitat use whilst rice is in its growing stages (Jones et al. 2017), refuge habitats for rats such as dense vegetation near rice fields should be cleared and sanitation around the rice field maintained regularly to minimize rodent activity in the rice field. Regular weeding of fields reduces cover and alternate food source for rodents (Drost and Moody 1982; Htwe et al. 2019; Puan et al. 2011). The timing of control, i.e. prior to the onset of breeding, is also critical (Brown et al. 2011; Htwe et al. 2019; Stuart et al. 2015).

Alternate Wetting and Drying (AWD) is classified as a water-smart, weather-smart and carbon-smart technology in rice production (Wassmann et al. 2019). AWD is also currently the only practice that has a "proven track record" in mitigating greenhouse gas emissions (Sander et al. 2015). We strongly support the adoption of AWD in lowland irrigated rice fields. The apprehension of farmers from Southeast Asia that to adopt intermittent drying of the rice fields will lead to higher rodent pest activity is not supported by our findings.

\section{ACKNOWLEDGEMENTS}

We thank the farmers of Minggir, Yogyakarta, Indonesia and Bula, Camarines Sur, Philippines for hosting this project. BPTP-Yogyakarta facilitated the collaboration with the famers of Minggir. Funding for this research was provided for by the Lee Foundation Rice Scholarship and the postgraduate platform of the Closing Rice Yield Gaps project (CORIGAP) which is funded by the Swiss Agency for Development and Cooperation (Grant Number 81016734) through the International Rice Research Institute.

\section{COMPLIANCE WITH ETHICAL STANDARDS}

Conflict of interest

The authors declare no conflict of interest.

Ethical approval 
Kill-trapping, live-capture, handling, marking and euthanasia of rodents conforms to the 2016 Guidelines of the American Society of Mammalogists for the use of wild mammals in research and education (Sikes and Animal Care \& Use Committee of the American Society of Mammalogists 2016) and the AVMA Guidelines for the Euthanasia of Animals: 2013 Edition (AVMA (American Veterinary Medical Association) 2013). Permits were secured from the Department of Environment and Natural Resources in the Philippines (R5-74 and R4A-WGP-2017-LAG-003), and the Kementerian Riset, Teknologi, Dan Pendidikan Tinggi (Ministry of Research, Technology, and Higher Education) in Indonesia (1169/FRP/E5/Dit.KI/V/2016 and 1192/FRP/E5/Dit.KI/VI/2017) prior to the conduct of the research.

\section{REFERENCES}

Abu Baker MA, Brown JS (2010) Islands of fear: Effects of wooded patches on habitat suitability of the striped mouse in a South African grassland Functional Ecology 24:1313-1322 doi:10.1111/j.13652435.2010.01757.x

Aplin KP, Brown PR, Jacob J, Krebs CJ, Singleton GR (2003) Field methods for rodent studies in Asia and the Indo-Pacific. ACIAR Monograph Series, vol 100. Australian Centre for International Agricultural Research, Melbourne

AVMA (American Veterinary Medical Association) (2013) AVMA Guidelines for the Euthanasia of Animals: 2013 Edition. American Veterinary Medical Association, Schaumburg, IL

Batschelet E (1981) Circular statistics in biology. Academic Press, New York

Benhamou S (2004) How to reliably estimate the tortuosity of an animal's path: straightness, sinuosity, or fractal dimension? Journal of Theoretical Biology 229:209-220 doi:https://doi.org/10.1016/j.jtbi.2004.03.016

Boonsong P et al. (1999) Rodent management in Thailand. In: Singleton GR, Hinds LA, Leirs H, Zhang Z (eds) Ecologically-based management of rodent pests. ACIAR Monograph No. 59 edn. Australian Centre for International Agricultural Research, Canberra, pp 338-357

Boonstra R, Craine ITM (1986) Natal nest location and small mammal tracking with a spool and line technique. Canadian Journal of Zoology 64:1034-1036 doi:https://doi.org/10.1139/z86-153

Bouman BAM, Lampayan RM, Tuong TP (2007) Water management in irrigated rice: coping with water scarcity. International Rice Research Institute, Los Banos, Philippines

Bouman BAM, Tuong TP (2001) Field water management to save water and increase its productivity in irrigated lowland rice. Agricultural Water Management 49:11-30 doi:https://doi.org/10.1016/S0378-3774(00)001281

Brown JS (1988) Patch use as an indicator of habitat preference, predation risk, and competition. Behavioral Ecology and Sociobiology 22:37-47 doi:https://doi.org/10.1007/BF00395696

Brown PR, Hung NQ, Hung NM, van Wensveen M (1999) Population ecology and management of rodent pests in the Mekong River Delta, Vietnam. In: Singleton GR, Hinds LA, Leirs H, Zhang Z (eds) Ecologically-based management of rodent pests. ACIAR Monograph No. 59. Australian Centre for International Agricultural Research, Canberra, pp 319-337

Brown PR, Phung NTM, Gaydon DS (2011) Rats in rice: linking crop and pest models to explore management strategies Wildlife Research 38:560-567 doi:https://doi.org/10.1071/WR10194

Brown PR, Singleton GR, Sudarmaji (2001) Habitat use and movements of the rice-field rat, Rattus argentiventer, in West Java, Indonesia. Mammalia 65:151-166 doi:https://doi.org/10.1515/mamm.2001.65.2.151

Brown PR, Tuan NP, Banks PB (2005) Movements, habitat use and response of ricefield rats to removal in an intensive cropping system in Vietnam. Belgian Journal of Zoology 135:1

Cunha AA, Vieira MV (2002) Support diameter, incline, and vertical movements of four didelphid marsupials in the Atlantic forest of Brazil. Journal of Zoology 258:419-426 doi:https://doi.org/10.1017/S0952836902001565

Dawe D (2005) Increasing Water Productivity in Rice-Based Systems in Asia - Past Trends, Current Problems, and Future Prospects. Plant Production Science 8:221-230 doi:https://doi.org/10.1626/pps.8.221

Drost D, Moody K (1982) Rat damage in weed control experiments in rainfed transplanted rice. International Journal of Pest Management 28:295-299 doi:https://doi.org/10.1080/09670878209370724

Fall MW (1977) Rodents in tropical rice. Rodent Research Center, University of the Philippines at Los Banos, College, Laguna 
GRiSP (Global Rice Science Partnership) (2013) Rice Almanac., 4th edn. International Rice Research Institute, Los Banos, Philippines

Htwe NM, Singleton GR, Johnson DE (2019) Interaction between rodents and weeds in a lowland rice agroecosystem in Myanmar: the need for an integrated approach to management. Integrative Zoology In press

IBM Corp. (2016) IBM SPSS Statistics for Windows, Version 24.0. IBM Corp. , Armonk, NY

Jacob J, Brown JS (2000) Microhabitat use, giving-up densities and temporal activity as short- and long-term antipredator behaviors in common voles. Oikos 91:131-138 doi:https://doi.org/10.1034/j.16000706.2000.910112.x

Jacob J, Matulessy J (2004) Effects of imposed sterility on movement patterns of female ricefield rats. Journal of Wildlife Management 68:1138-1144 doi:https://doi.org/10.2193/0022541X(2004)068[1138:EOISOM]2.0.CO;2

Jacob J, Nolte D, Hartono R, Subagja J, Sudarmaji (2003a) Pre-and post-harvest movements of female rice-field rats in West Javanese rice fields. In: Singleton GR, Hinds L, Krebs CJ, Spratt DM (eds) Rats, mice and people: rodent biology and management. Australian Centre for International Agricultural Research, Canberra, pp 277-280

Jacob J, Sudarmaji, Singleton GR (2003b) Ecologically based management of rice-field rats on a village scale in West Java: experimental approach and assessment of habitat use. In: Singleton GR, Hinds LA, Krebs CJ, Spratt DM (eds) Rats, mice and people: rodent biology and management., vol 96. Australian Centre for International Agricultural Research, Canberra, pp 191-196

John A (2014) Rodent outbreaks and rice pre-harvest losses in Southeast Asia. Food Security 6:249-260 doi:https://doi.org/10.1007/s12571-014-0338-4

Johnson-Beebout SE, Angeles OR, Alberto MCR, Buresh RJ (2009) Simultaneous minimization of nitrous oxide and methane emission from rice paddy soils is improbable due to redox potential changes with depth in a greenhouse experiment without plants. Geoderma 149:45-53 doi:https://doi.org/10.1016/j.geoderma.2008.11.012

Jones CR, Lorica RP, Villegas JM, Ramal AF, Horgan FG, Singleton GR, Stuart AM (2017) The stadium effect: rodent damage patterns in rice fields explored using giving-up densities. Integrative Zoology 12:438-445 doi:https://doi.org/10.1111/1749-4877.12251

Kearney N, Handasyde K, Ward S, Kearney M (2007) Fine-scale microhabitat selection for dense vegetation in a heathland rodent, Rattus lutreolus: insights from intraspecific and temporal patterns. Austral Ecology 32:315-325 doi:https://doi.org/10.1111/j.1442-9993.2007.01697.x

Krebs CJ (1966) Demographic changes in fluctuating populations of Microtus californicus. Ecological Monographs 36:239-273 doi:https://doi.org/10.2307/1942418

Krijger IM, Belmain SR, Singleton GR, Groot Koerkamp PW, Meerburg BG (2017) The need to implement the landscape of fear within rodent pest management strategies. Pest Management Science 73:2397-2402 doi:https://doi.org/10.1002/ps.4626

Lam YM (1983) Reproduction in the rice field rat, Rattus argentiventer. Malayan Nature Journal 36:249-282

Lampayan RM, Rejesus RM, Singleton GR, Bouman BA (2015) Adoption and economics of alternate wetting and drying water management for irrigated lowland rice. Field Crops Research 170:95-108 doi:https://doi.org/10.1016/j.fcr.2014.10.013

Laundré JW, Hernández L, Altendorf KB (2001) Wolves, elk, and bison: reestablishing the" landscape of fear" in Yellowstone National Park, USA. Canadian Journal of Zoology 79:1401-1409 doi:https://doi.org/10.1139/z01-094

Leung LK-P et al. (2007) Selecting bait base to increase uptake of zinc phosphide and warfarin rodenticide baits. Crop Protection 26:1281-1286 doi:https://doi.org/10.1016/j.cropro.2006.11.002

Leung LKP, Singleton GR, Sudarmaji, Rahmini (1999) Ecologically-based population management of the rice-field rat in Indonesia. In: Singleton GR, Hinds LA, Leirs H, Zhang Z (eds) Ecologically-based management of rodent pests. ACIAR Monograph No. 59 edn. Australian Centre for International Agricultural Research, Canberra, pp 305-318

Loretto D, Vieira MV (2005) The effects of reproductive and climatic seasons on movements in the black-eared opossum (Didelphis aurita Wied-Neuwied, 1826). Journal of Mammalogy 86:287-293 doi:https://doi.org/10.1644/BEH-117.1

Marges B (1972) Reproduction and seasonal abundance of the ricefield rat (Rattus rattus mindanensis Mearns) at Siniloan, Laguna. Masters thesis, University of the Philippines

Meerburg BG, Singleton GR, Leirs H (2009) The Year of the Rat ends - time to fight hunger! Pest Management Science 65:351-352 doi:https://doi.org/10.1002/ps.1718 
Miller C, Christman MC, Estevez I (2011) Movement in a confined space: Estimating path tortuosity. Applied Animal Behaviour Science 135:13-23 doi:https://doi.org/10.1016/j.applanim.2011.09.002

Miller RW (2007) Rattus tanezumi in the upland rice terraces of Banaue, Philippines: demography, habitat use, crop damage, and yield assessment. Masters thesis, The University of New South Wales

Miller RW, Stuart AM, Joshi RC, Banks PB, Singleton GR (2008) Biology and management of rodent communities in complex agroecosystems-rice terraces. In: Singleton GR, Joshi RC, Sebastian LS (eds) Philippine Rats: Ecology and Management. Philippine Rice Research Institute, Science City of Munoz, Nueva Ecija, Philippines, pp 25-36

Mohr K, Vibe-Petersen S, Jeppesen LL, Bildsøe M, Leirs H (2003) Foraging of multimammate mice, Mastomys natalensis, under different predation pressure: cover, patch-dependent decisions and density-dependent GUDs. Oikos 100:459-468 doi:https://doi.org/10.1034/j.1600-0706.2003.11763.x

My Phung NT, Brown PR, Leung LKP (2012) Changes in population abundance, reproduction and habitat use of the rice-field rat, Rattus argentiventer, in relation to rice-crop growth stage in a lowland rice agroecosystem in Vietnam. Wildlife Research 39:250-257 doi:https://doi.org/10.1071/WR11153

Pan J et al. (2017) Grain yield, water productivity and nitrogen use efficiency of rice under different water management and fertilizer-N inputs in South China. Agricultural Water Management 184:191-200 doi:https://doi.org/10.1016/j.agwat.2017.01.013

Peel MC, Finlayson BL, McMahon TA (2007) Updated world map of the Köppen-Geiger climate classification. Hydrology and Earth System Sciences Discussions 4:439-473 doi:https://doi.org/10.5194/hess-11-1633$\underline{2007}$

Prevedello JA, Rodrigues RG, Monteiro-Filho ELA (2009) Vertical use of space by the marsupial Micoureus paraguayanus (Didelphimorphia, Didelphidae) in the Atlantic Forest of Brazil. Acta Theriologica 54:259266 doi:https://doi.org/10.4098/j.at.0001-7051.063.2008

Puan C, Goldizen A, Zakaria M, Baxter G (2011) Understanding of relationships between ground cover and rat abundances: An integrative approach for management of the oil palm agroecosystem. Crop Protection 30:1263-1268 doi:https://doi.org/10.1016/j.cropro.2011.05.025

Pujiastuti Y, Sitompul KB, Suparman S, Weni HW, Herlinda S, Hadi BA (2018) Study on Trap Barrier System Towards Rodent Population and Rice Production in Tidal-Area of South Sumatera Indonesia. AGRIVITA, Journal of Agricultural Science 40 doi:http://doi.org/10.17503/agrivita.v40i3.1633

Quynh VD, Sander BO (2015) Applying and scaling up alternate wetting and drying technology for paddy rice in the Mekong River Delta. CGIAR Research Program on Climate Change, Agriculture and Food Security (CCAFS), Can Tho City, Vietnam

R Core Team (2018) R: A language and environment for statistical computing. R Foundation for Statistical Computing, Vienna, Austria

Rejesus RM, Palis FG, Rodriguez DGP, Lampayan RM, Bouman BAM (2011) Impact of the alternate wetting and drying (AWD) water-saving irrigation technique: evidence from rice producers in the Philippines. Food Policy 36:280-288 doi:https://doi.org/10.1016/j.foodpol.2010.11.026

Richards M, Sander BO (2014) Alternate wetting and drying in irrigated rice. CGIAR Research Program on Climate Change, Agriculture and Food Security (CCAFS), Copenhagen, Denmark

Sander BO, Wassmann R, Siopongco J, Hoanh C, Johnston R, Smakhtin V (2015) Mitigating greenhouse gas emissions from rice production through water-saving techniques: potential, adoption and empirical evidence. In: Hoanh C, Smakhtin V, Johnston R (eds) Climate Change and Agricultural Water Management in Developing Countries. CAB International, Wallingford, UK, pp 193-207

Sikes RB, Animal Care \& Use Committee of the American Society of Mammalogists (2016) 2016 Guidelines of the American Society of Mammalogists for the use of wild mammals in research and education. Journal of Mammalogy 97:663-688 doi:https://doi.org/10.1093/jmammal/gyw078

Sikes RS, Gannon WL (2011) Guidelines of the American Society of Mammalogists for the use of wild mammals in research. Journal of Mammalogy 92:235-253 doi:https://doi.org/10.1644/10-MAMM-F-355.1

Singleton GR (2003) Impacts of rodents on rice production in Asia. International Rice Research Institute, Los Banos, Laguna

Singleton GR, Hinds LA, Krebs CJ, Spratt DM (2003) Rats, mice and people: rodent biology and management. Australian Centre for International Agricultural Research, Canberra, Australia

Siopongco JDLC, Wassmann R, Sander BO (2013) Alternate wetting and drying in Philippine rice production: feasibility study for a Clean Development Mechanism. International Rice Research Institute (IRRI), Los Baños, Philippines

Smedley RE (2017) Avian diversity of rice fields in Southeast Asia. Dissertation, University of Reading 
Strauss A, Solmsdorff KY, Pech R, Jacob J (2008) Rats on the run: removal of alien terrestrial predators affects bush rat behaviour. Behavioral Ecology and Sociobiology 62:1551-1558 doi:https://doi.org/10.1007/s00265008-0584-6

Stuart AM, Prescott CV, Singleton GR (2012) Natal nest locations of the Asian house rat (Rattus tanezumi) in lowland rice-coconut cropping systems: a coconut penthouse or rice bunds with water frontage? Wildlife Research 39:496-502 doi:https://doi.org/10.1071/WR11197

Stuart AM, Prescott CV, Singleton GR (2014) Habitat manipulation in lowland rice-coconut cropping systems of the Philippines - an effective rodent pest management strategy? Pest Management Science 70:939-945 doi:https://doi.org/10.1002/ps.3631

Stuart AM, Prescott CV, Singleton GR, Joshi RC, Sebastian LS (2007) The rodent species of the Ifugao Rice Terraces, Philippines-target or non-target species for management? International Journal of Pest Management 53:139-146 doi:https://doi.org/10.1080/09670870701192433

Stuart AM, Singleton GR, Prescott CV (2015) Population ecology of the Asian house rat (Rattus tanezumi) in complex lowland agroecosystems in the Philippines. Wildlife Research 42:165-175

Swanepoel LH et al. (2017) A systematic review of rodent pest research in Afro-Malagasy small-holder farming systems: Are we asking the right questions? PLOS ONE 12:e0174554 doi:https://doi.org/10.1371/journal.pone.0174554

Tristiani H, Priyono J, Murakami O (1998) Seasonal changes in the population density and reproduction of the ricefield rat, Rattus argentiventer (Rodentia: Muridae), in West Java. Mammalia 62:227-240 doi:https://doi.org/10.1515/mamm.1998.62.2.227

Valdivia CMD, Sumalde ZM, Palis FG, Lampayan R, Umali C, Singleton GR (2016) Effects of alternate wetting and drying on rice farming in Bohol, Philippines. Philippine Journal of Crop Science 41:50-56

Wassmann R, Villanueva J, Khounthavong M, Okumu B, Vo T, Sander B (2019) Adaptation, mitigation and food security: Multi-criteria ranking system for climate-smart agriculture technologies illustrated for rainfed rice in Laos. Global Food Security 23:33-40 doi:https://doi.org/10.1016/j.gfs.2019.02.003 